\title{
THE \\ AMAZON FOREST
}

\begin{tabular}{|c|c|}
\hline & Tropical rain forest (Selva) \\
\hline & Scrub woodland (Cerradão) \\
\hline & Wet savanna \\
\hline & Dry savanna (Caatinga) \\
\hline & Swamps \\
\hline & Agricultural settlement zone \\
\hline 2 & Forest clearing \\
\hline & Planned forest reserve \\
\hline $\boldsymbol{\nabla}$ & Cattle raising \\
\hline
\end{tabular}

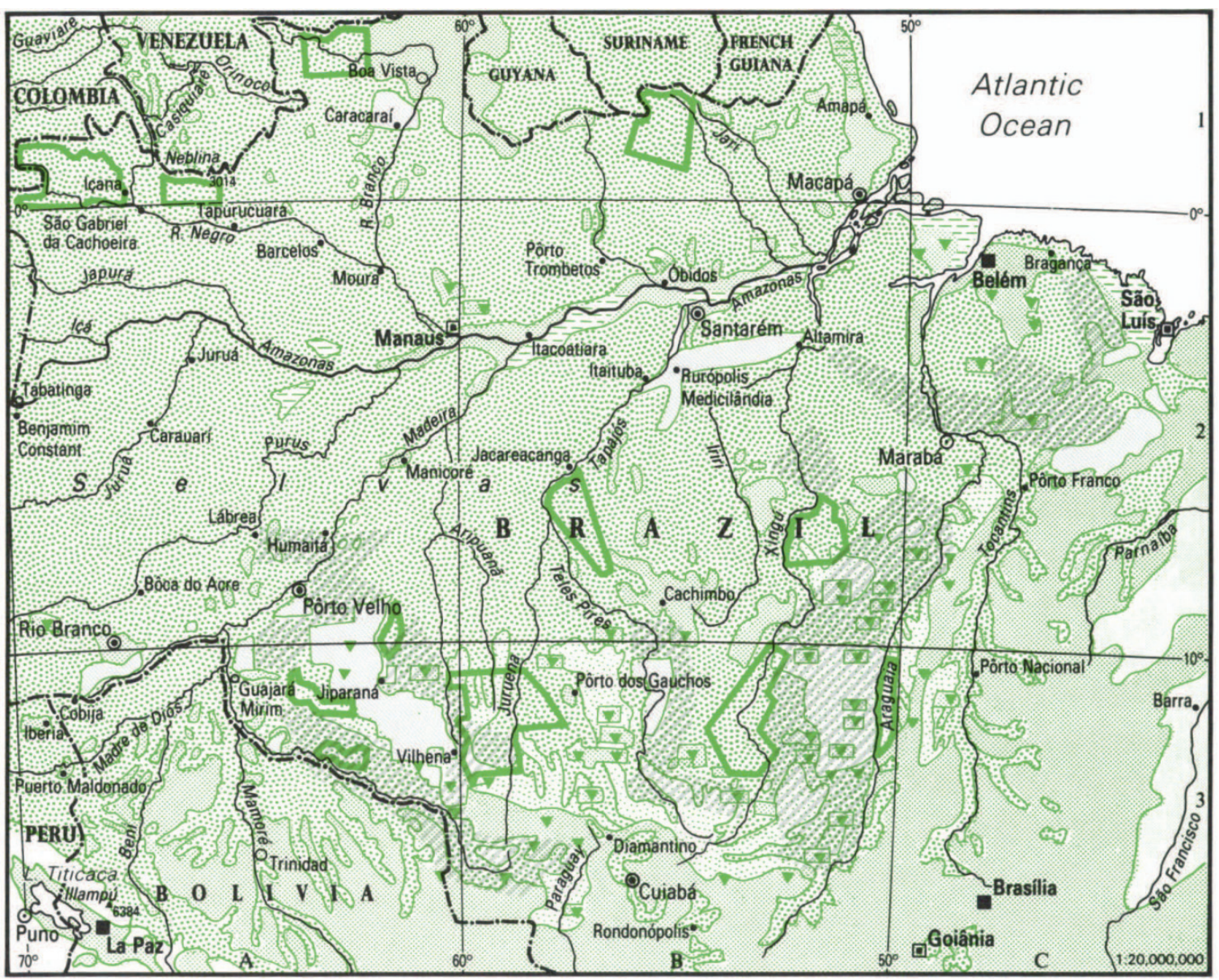

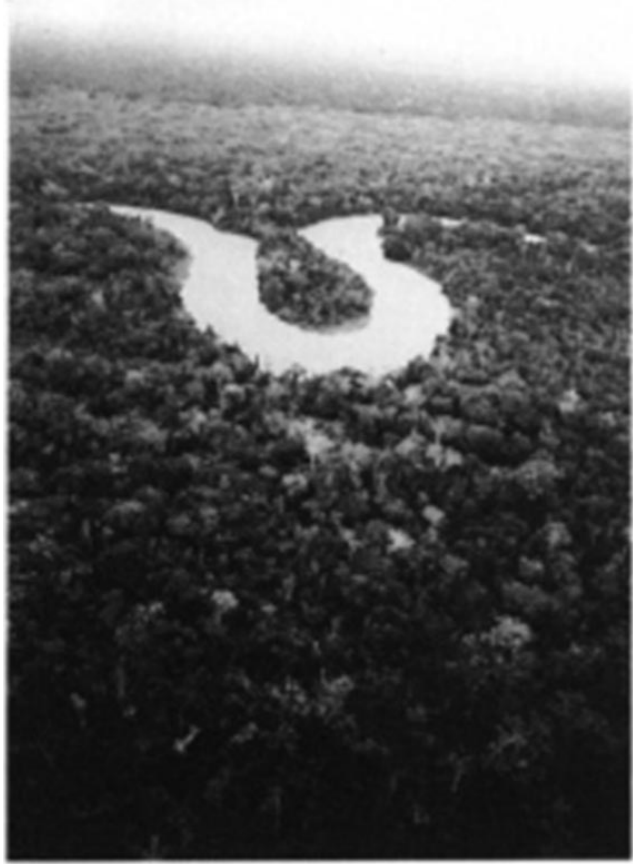

Most of the Amazon Basin is covered with dense tropical rain forest comprised of many different species of trees and shrubs, often hundreds of different species per square kilometer. These are by far the world's most extensive and rich virgin forests. The forests are often less dense and even patchy on the highland fringes of the basin. The prevalent belief that the tropical soils of the Amazon Basin are fertile is, to a large extent, unfounded. The soils over most part of the basin are leached out of valuable mineral content and often coarse. The fertile soils of the basin are mostly confined to the river floodplains where fresh silt is deposited almost annually.

European penetration into the Amazon Basin during the seventeenth and eighteenth centuries led mainly to the establishment of a number of Jesuit missionary stations on the banks of the Amazon and some of its chief tributaries. The Jesuits were engaged in efforts to Christianize the small indigenous Indian tribes and settle them in villages near these stations. The heart of the basin experienced a short economic boom during the second half of the nineteenth and the early twentieth century, when it became the world's source of rubber tapped from naturally grown rubber trees that were found in abundance in part of the rain forest. Large numbers of workers, mainly from northeastern Brazil, were attracted to the rubber-producing area centered in Manaus, which grew from a small settlement to a town of over 50,000. Exports rose from a few tons in the 1850 s to 42,000 tons in 1912. The boom ended in the 1920s when large-scale production of rubber from plantations in Southeast Asia (mainly Malaya) made the extraction of rubber from the natural forests unprofitable. Brazil's rubber production diminished to a trickle. Most workers employed in this industry left the region.
Since the 1960s the Amazon lowlands have become one of the main development targets of the Brazilian government. This has been prompted by the desire to realize a long-standing wish to extend effective control over a large part of Brazil's territory, to exploit the vast resources of the region and integrate it into the expanding Brazilian economy, and to solve the problem of overpopulation, unemployment, and poverty in the northeastern region. Brazil is planning to settle in the lowlands 100,000 familes, a large proportion of whom will be engaged in agriculture on land allotted to them mainly along the east-west axis of the TransAmazon (Transamazônica) Highway constructed in (1970-1975) across the Amazon Basin. This highway was augmented by a number of additional north-south roads designed to open up wide parts of the Amazon Basin. Planned settlement during the 1970s and early 1980s developed much slower than anticipated and encountered unforeseen difficulties. Unplanned and unsupervised settlement by squatters, speculators, profiteers, and miners (mainly gold prospectors) taking advantage of the development facilities and access created by the government, has proliferated, however. This led to extensive clearing of forest areas and callous disregard of the interests of aboriginal Indian tribes. The progress of economic activites in the Brazilian Amazon has produced growing controversy in Brazil and worldwide; critics point out especially the indifference toward local and global environmental effects caused by massive destruction of the world's principal and largest remaining tropical forest. 